\title{
Poststrukturalisti križem rok opazujejo svet v plamenih: izhod iz samoustvarjene krize "arhitekturne kulture»
}

V članku se kritizira kriza, ki trenutno vlada med poklici $s$ področja okoljskega načrtovanja: vodilni se soočajo z nujnimi ekološkimi, socialnimi in ekonomskimi obvezami, obenem pa so obtičali v zmedi brezbrižne postmodernistične umetniške doktrine. Rezultat je stanje paralize, ki so si ga nakopali sami in dopušča, da se nezaslišane napake iz preteklosti ponavljajo v nedogled, pri čemer je pomembno samo to, da so odete v vse bolj estetsko ekstravagantna umetniška oblačila. Do te paralize, ki upravičuje sama sebe, prihaja, ker zaradi poststrukturalistične zaslepljenosti z dvoumnostjo, raznolikostjo in izmišljenim pomenom učinkovit skupni okvir, ki bi obravnaval žgoče vprašanje grajenega okolja, postane nemogoč. Ta paraliza pa je nagrajena, saj služi ozkim ekonomskim interesom tistih, ki z veseljem prisluhnejo zagovoru izvedbe projektov, ki bi bili zaradi slabše kakovosti sicer lahko zavrnjeni. Članek se konča z obetavno ugotovitvijo, da se sestavine takega okvira dejansko pojavljajo v bioloških vedah in na drugih področjih. Da pa bi jih lahko dobro izkoristili, se morajo strokovnjaki naučiti kritizirati napačne rabe neproduktivnih oblik razmišljanja in tudi, kako shajati brez njih; več teh oblik je opisanih v članku. Upamo, da bo članek vsaj majhen korak na tej pomembni poti.

Ključne besede: kritika okoljskega načrtovanja, arhitekturna kultura, poststrukturalizem, postmodernizem, poklicna odgovornost 


\section{Uvod}

Strah se potika med poklici s področja okoljskega načrtovanja: strah pred marginalizacijo in nepomembnostjo, in to po največji gospodarski krizi naše dobe, ki se bo najverjetneje kmalu sprevrgla tudi v veliko ekološko krizo. V času, $\mathrm{v}$ katerem se od teh poklicev zahteva, naj razvijajo bolj trajnostna, odpornejša in človeku prijaznejša naselja, ti namesto tega ponujajo - običajno naivnim strankam v državah v razvoju - zanimivo zmes vse bolj eksotičnih stvaritev, navidezne okolju prijazne retorike, in kadar so tarče upravičenih kritik, teoretičnih zagovorov obupavajočega postmodernističnega nihilizma (Koolhaas, 1995; Frampton, 2005; La Giorgia, 2007; Lewis, 2011).

Žalitev nas boli še toliko bolj, ker so bili prav ti poklici pravzaprav eni od glavnih povzročiteljev ekološkega in gospodarskega poloma. Članek na kratko opisuje, kako je prišlo do te poklicne malomarnosti, kakšne so neposredne posledice izčrpavanja naftnih zalog in drugih virov, kakšen davek so za to plačali ljudje ter zakaj ti poklici še naprej slepo vztrajajo pri svojem početju in niso zmožni oziroma nočejo popraviti svojih grozljivih napak. Razlog za to je zgodovinski premik v načrtovalski kulturi, in sicer premik od celostnega pristopa k zadovoljevanju človekovih potreb proti specializiranemu pristopu $\mathrm{k}$ okoljskemu načrtovanju, ki predvsem » upodablja umetnost « $\mathrm{z}$ vsemi svojimi dvoumnimi razvadami in v zadnjem času skoraj neomejenimi muhami postmodernistične in poststrukturalistične rahločutnosti.

Vodilni načrtovalci so veselo unovčili ta umetnostni »biankoček « in z njim upravičili množico grehov. Najprej so »komodifikacijo « objokovali, nato pa so jo začeli kar najbolj tudi sami izkoriščati. Posmehovali so se gibanjem, ki so poskušala reformirati predmestna naselja, ne da bi pri tem sami prevzeli skupno poklicno odgovornost za ustvarjanje predmestij, razdrobljenih $\mathrm{z}$ avtocestami, in pusto arhitekturo »velikih škatel « (z minimalnim okrasjem, prilepljenim na pročlja), ki so si jih sami izmislili. Kar je še slabše, ustvarili so zapleteno poststrukturalistično pripoved, ki namiguje, da ne moremo ničesar storiti, da so na delu veliko močnejše sile ter da lahko samo sodelujemo v igri in upamo na občasne izjemne ali vsaj domiselne dekonstrukcije resnice.

To »čarobno razmišljanje « se ne razlikuje veliko od razmišljanja starodavnih ljudstev, ki so risala na stene jam in verjela, da jim bodo čudovite slike srnjadi na stenah naslednji dan priklicale dober ulov. Če je naša umetnost dovolj lepa, bomo zagotovo ustvarili čudovita mesta. Večina ljudi se zaveda, da je to navadna norost, poststrukturalistični arhitekti pa so uspeli več tisoč ambicioznih študentov elegantno prepričati, da to ni samo norost, temveč čista ironična genialnost.
Poleg tega je »umetniškim načrtovalcem « pomagala tudi gradbena industrija, za katero je bil umetniški pristop vedno uporabno in prepričljivo okrasje, ki so ga lahko dodali spornim projektom. »Če ne marate našega projekta, je to zato, ker ste filistri ter ne razumete velike upodabljajoče umetnosti in zapletene sodobne kulture«, radi rečejo. Obtožba, da so nazadnjaški, je bila zato močno orožje, s katerim so utišali tiste, ki so želeli zaščititi soseske in zgodovinske stavbe ter ranljive skupnosti oziroma katere koli žrtve spornega projekta. S pojavom poststrukturalizma pa je bila temu »umetniško-industrijskemu kompleksu « podeljena najbolj posebna oblika biankočeka za gradbene projekte, ki se spretno skriva za »kompleksnostjo «, » protislovjem «, » mnogovrstnostjo pogledov « in »raznolikostjo pomenov « ter na podlagi katere se lahko gradi skoraj kar koli skoraj kjer koli. Pri tem smo žrtvovali svojo sposobnost učenja iz lastnih napak, ponavljanja uspehov in dejanskega reševanja svojih perečih vprašanj ali, $\mathrm{z}$ drugimi besedami, našo skupno inteligenco. Še vedno pa to nekaterim prinaša kratkoročno korist.

Z veliko mero upanja pa lahko sklepamo, da dejansko imamo orodja, metode in načine razmišljanja o svojih problemih, $s$ katerimi lahko te probleme razumemo in rešimo. Nekateri so opisani na koncu članka. To pa bo zahtevalo drugačen način razmišljanja $\mathrm{o} \gg$ vrsti problema, ki ga pomeni mesto «, kot pravi Jane Jacobs (1961: 429). Poleg tega bi morala stroka v večji meri priznati krizo, ki so jo opisani poklici ustvarili sami sebi, in se bolj zavzeti za to, da se ta reši. Upava, da bo članek vsaj majhen korak v smeri širše in nujno potrebne strokovne samokritike in učenja na lastnih napakah oziroma iz lastnih izkušenj.

\section{2 Življenje na izposojeni nafti}

Vzorec, razviden iz zemljevidov, ki prikazujejo zaplembe nepremičnin zaradi neplačevanja hipotek v mestih v ZDA - središču svetovne gospodarske krize, ki je izbruhnila leta 2008 -, je prvi prepričljiv podatek $\mathrm{v}$ naši zgodbi. $\mathrm{V}$ mestih se ob zunanjem obroču oblikujejo močni grozdi predmestij, v katera so se ljudje pripravljeni voziti zaradi cenejših stanovanj; to so oddaljena mestna območja, ki zahtevajo uporabo avtomobila; zanje nudijo poceni hipoteke z možnostjo odloga odplačila, nahajajo pa se daleč od delovnih mest in storitev. Znotraj teh obročev, za katere je značilen visok odstotek zaplemb, pa je na gosteje poseljenih urbanih območjih veliko manj zaplemb. Ni naključje, da so ta notranja območja bolj strnjena, lažje prehodna in bolje povezana $\mathrm{z}$ javnim potniškim prometom; tu je manj izpustov $\mathrm{CO}_{2}$, obenem pa so ta območja manj občutjiva za narǎ̌čajoče stroške energije, ki so mnoge lastnike stanovanj potisnili čez rob in sprožili val neplačevanja hipotekarnih kreditov. Vse to je leta 2008 vodilo neposredno v svetovno finančno krizo in posledično $\mathrm{v} \gg$ veliko recesijo «. Višje cene energije, ciklična recesija in refinanciranje netrajnostnih poceni 


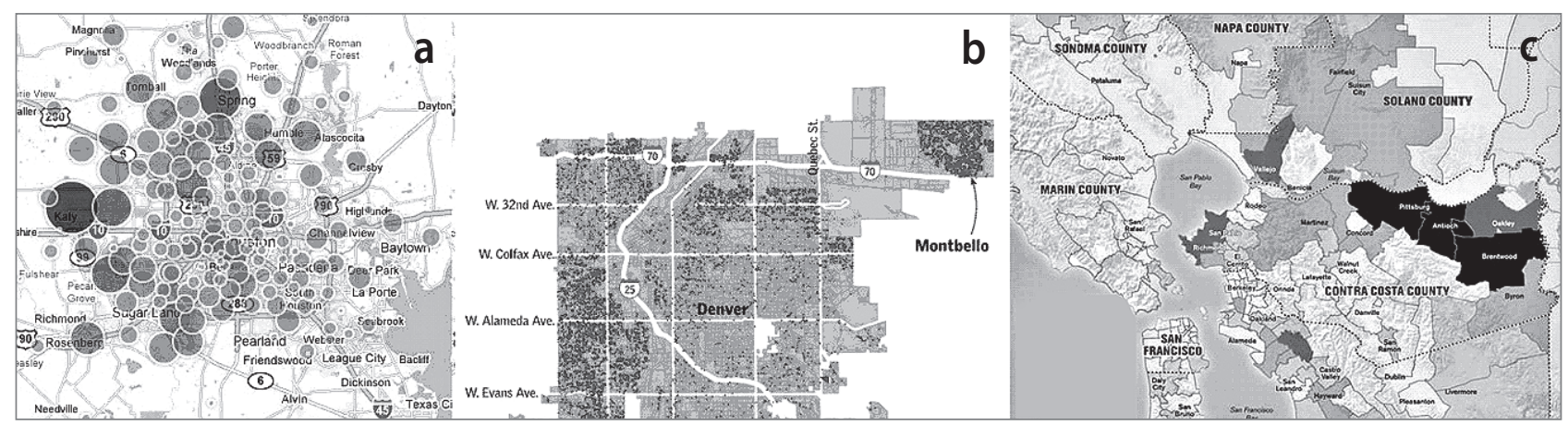

Slika 1: Vzorci zaplemb stanovanjskih nepremičnin, iz katerih je razviden veliko višji odstotek zaplemb v oddaljenih zunanjih predmestjih, v katera so se ljudje pripravljeni voziti zaradi cenejših stanovanj; (a) zaplembe v Houstonu (večji krogi označujejo višjo stopnjo zaplemb); (b) zaplembe v Denverju (pike označujejo posamezne zaplenjene nepremičnine); (c) zaplembe v Dallasu (črna označuje območja z visoko stopnjo, bela pa območja z nizko stopnjo zaplemb; ilustracija: (a) Houston Chronicle; (b) Denver Post; (c) San Francisco Chronicle).

hipotekarnih kreditov z možnostjo odloga plačila so skupaj povzročili »vihar « ekonomskih stisk (slika 1). Pri tem pa ni šlo le za izreden dogodek, ampak najverjetneje za oznanilo, da bo le še huje, če ne bomo rešili glavnih problemov, ki so to povzročili: prepletajočo se neučinkovitost financ, predpisov, rabe energije in, seveda, okoljskega načrtovanja (Leinberger, 2008).

Za naša gospodarstva so bile v zadnjem stoletju značilne netrajnostne navade, ki jih je omogočala poceni nafta; zaradi njih bomo kmalu naleteli na težave. Gre za navade v praksi ter tudi v vzorcih mišljenja in sistemih vrednot, prava, standardov, ukrepanja in neukrepanja. Tvorijo nekakšen veliki »operacijski sistem «, na katerem temeljijo vse večje igre, v katerih sodeluje več igralcev in ki oblikujejo svet, kakršnega poznamo danes, ter zajemajo obsežen mozaik dejavnosti. Lahko bi rekli, da je ta sistem deloma slab in deloma dober, ampak nauk je preprost: tako ne gre več naprej. Treba je spremeniti nekatere pomembne stvari, saj se vzorci netrajnostnega urbanega razvoja in rasti vse bolj krepijo (slika 2). Le redki podpirajo nenačrtno širjenje ameriških predmestij, saj menijo, da imajo slabo obliko nase-

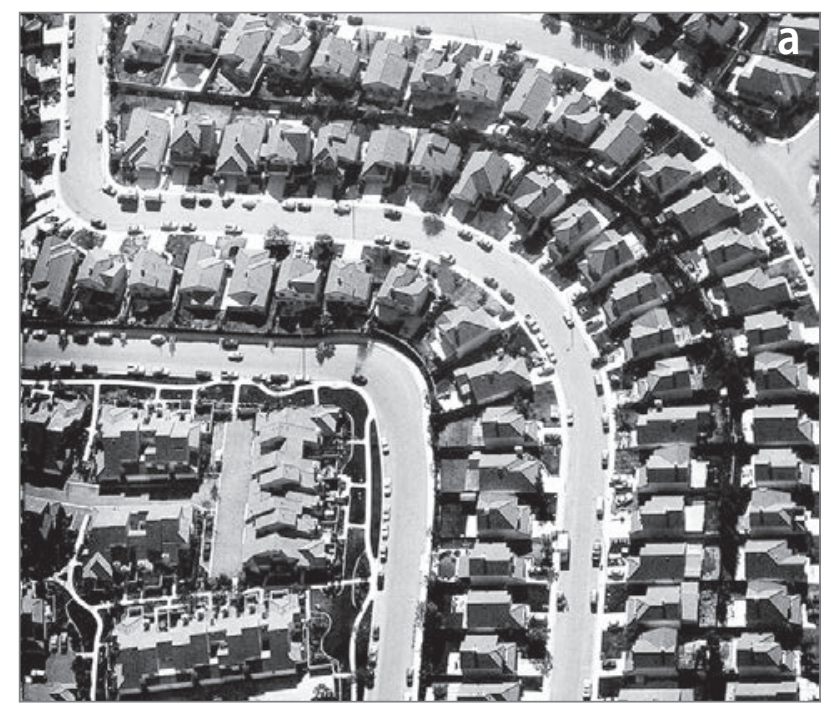

lij; izjema je majhna in vztrajna skupina zagovornikov politike laissez-faire in strokovnih apologetov, ki na ta račun dobro služijo. Le redki podpirajo neprivlačna nakupovalna središča in bencinske postaje ali pa izgubo travnika ali koruznega polja zaradi parkirišča, umazanega z nafto. Le peščica jih meni, da so predmestja lepa ali da se tista starejša lepo starajo. Poleg tega obstaja moteč občutek (čeprav ni jasno izražen), da je ta neprivlačnost močno povezana z netrajnostjo območij. Biologi nam zatrjujejo, da to morda res drži: prelep travnik je trajnosten, ker je njegova zgradba dosegla zapleteno in trdno ravnotežje - vzorec, ki se nam samodejno zdi čudovit (Kellert in Wilson, 1993; Kellert idr., 2008).

Ta ameriški proizvod, ki se vse bolj širi, se izvaža po vsem svetu: suburbanizacija, fragmentacija, skazitev, tratenje in izčrpavanje virov, ogrožanje zdravja in dobrega počutja ter ekološko opustošenje (Burchell idr., 2002; Frumkin idr., 2004; Program Združenih narodov za naselja, 2011). Kljub najboljšim prizadevanjem arhitektov in načrtovalcev - ali pa zaradi njih - se zdi, da je na delu ta žalostna formula: novejšs $=$ grše $=$ več

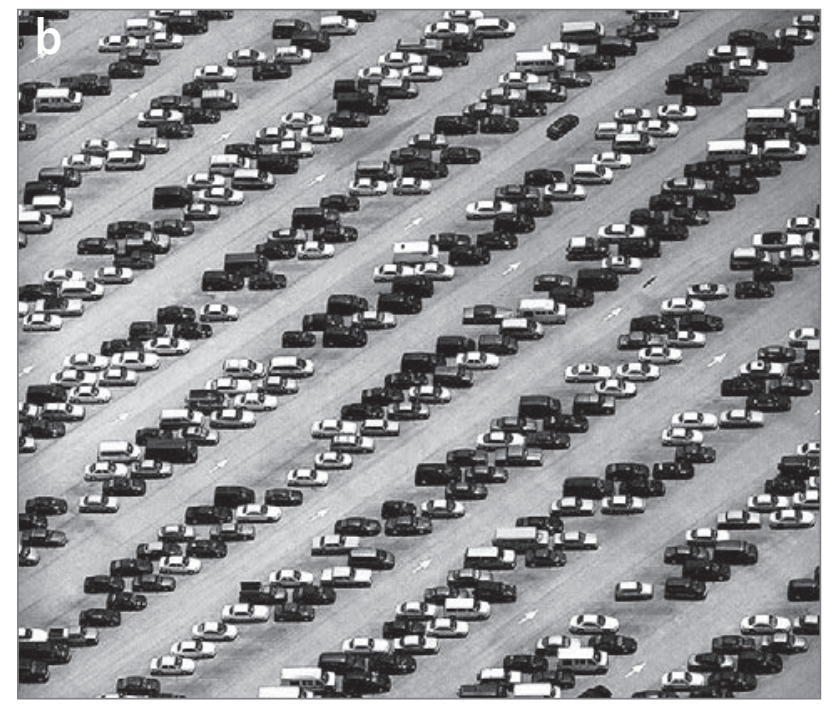

Slika 2: Nenačrtno širjenje mest ter prevlada pokrajin, v katerih so prebivalci odvisni od avtomobila in družbe fosilnih goriv; (a) model hitro rastočih predmestnih območij (ang. boomburbs), ki sta ga razvila Robert Lang in Patrick Simmons; (b) tipologije širjenja mest »asfaltnega naroda«, kot jih je razvila Jane Holtz Kay (foto: Jim Wark). 
tratenja virov $=$ več ekološke škode. Celo režim trajnostnih zgradb se zdi kot kruta šala, saj niti najboljši projekti niso načrtovani tako, da bi trajali več kot pol stoletja - gre za nenavadno definicijo izraza »trajnosten «. Na kraju zločina lahko najdemo prstne odtise poklicev s področja okoljskega načrtovanja. $\mathrm{Na}$ mesto da bi pomagali odpraviti škodo, so eni njenih glavnih povzročiteljev; zdaj pa si izmišljajo razloge za njen pojav, krivijo druge (pohlepne bankirje in naftne družbe, zagovornike laissez-faire itd.) in upravičujejo svojo krivdo.

Ta razdrobljena, od avtomobilov odvisna predmestja izvirajo prav iz pretirano segregiranih in racionaliziranih eksurbanih reformističnih shem Ebenezerja Howarda (1902) in drugih načrtovalcev vrtnih mest ter tudi poznejše generacije modernističnih arhitektov in načrtovalcev, kot je bil Le Corbusier (1923, 1935), ki je svoj utopični (vendar na koncu zelo uspešen) načrt gospodarskega razvoja utemeljil prav na predmestjih, odvisnih od avtomobila, ki kar požirajo nafto; to je presenetljivo odkrito opisal $\mathrm{v}$ knjigi z naslovom La ville radieuse iz leta 1935 (ki je bila leta $1967 \mathrm{v}$ angleščino prevedena kot Radiant City): »Mesta bodo del pokrajine; živel bom 30 milj od svoje pisarne $\mathrm{v}$ eno smer, pod borovcem; moja tajnica bo prav tako živela 30 milj od pisarne, v nasprotni smeri, pod drugim borovcem. Oba bova imela svoj avto. Obrabljala bova gume, cestne površine in opremo ter trošila nafto in bencin; vse to bo zahtevalo veliko dela /.../ ki ga bo dovolj za vse. «(Le Corbusier, 1967: 74.)

Investitorji in drugi zainteresirani iz gospodarstva so to utemeljitev rade volje uporabili za upravičevanje spornih projektov, kmalu pa so se jim pri tem pridružile tudi vlade. Arhitekturni in okoljski zločin, ki se je začel z Le Corbusierjevim osuplji- vim (in, hvala bogu, neuspelim) predlogom rušenja zgodovinskega središča Pariza in drugih evropskih mest, je svoj vrhunec dosegel z ekonomsko, rasno in kulturno segregiranimi človeškimi silosi, kot so na primer Pruitt-Igoe v Saint Louisu (glej De Decker in Newton, 2009), Cabrini Green v Čikagu in švicarska stanovanjska pošast v Le Lignonu v občini Vernier. To načrtovalsko mišljenje, naravnano $\mathrm{k} \gg$ megablokom $\ll$, vztraja še danes, ampak zdaj v segregiranih meščanskih enklavah, ki so kvantni skok k odvisnosti od avtomobilov in fosilnih goriv; najdemo jih lahko vse od Kitajske, zalivskih držav in Brazilije do Indije. Njihova glavna značilnost je razdrobljenost, razčlovečujoče odtujevanje pa je davek, ki ga mora plačevati tamkajšnje ranljivo prebivalstvo (ki je natlačeno vanje ali pa pozabljeno zunaj njih; slika 3).

To je $\mathrm{v}$ dobrem in slabem poganjalo rast $\mathrm{v}$ zadnjih petdesetih letih, načrte pa je v precejšnji meri oblikovala vodilna osebnost modernega okoljskega načrtovanja. Pri tem so bile porabljene ogromne količine nafte in bencina skupaj z netrajnostnimi količinami drugih virov. Raziskave kažejo, da ameriška predmestja proizvedejo tako ogromno količino izpustov $\mathrm{CO}_{2}$, da ne bi nič pomagalo, tudi če bi uspeli obvladati vse druge povzročitelje izpustov toplogrednih plinov ${ }^{[1]}$ (Wackernagel idr., 1997). Kljub temu je skrb vzbujajoče, da se strokovnjaki le malo zavedajo verjetnih posledic dejstva, da se ta katastrofalni model v velikem obsegu gradi še danes, in sicer v hitro razvijajočih se gospodarstvih v različnih delih sveta. Ena teh posledic je politične narave: pričakovano sporočilo podnebne konference v Köbenhavnu leta 2009 je bilo: »Ne pridigajte nam o zmanjševanju izpustov $\mathrm{CO}_{2}$, dokler ne dobimo svojega deleža tistega, v čemer pogoltni ameriški potrošniki $\mathrm{CO}_{2}$ še naprej uživajo «. Najosupljivejše pa je bilo to, kako hitro se je načrt
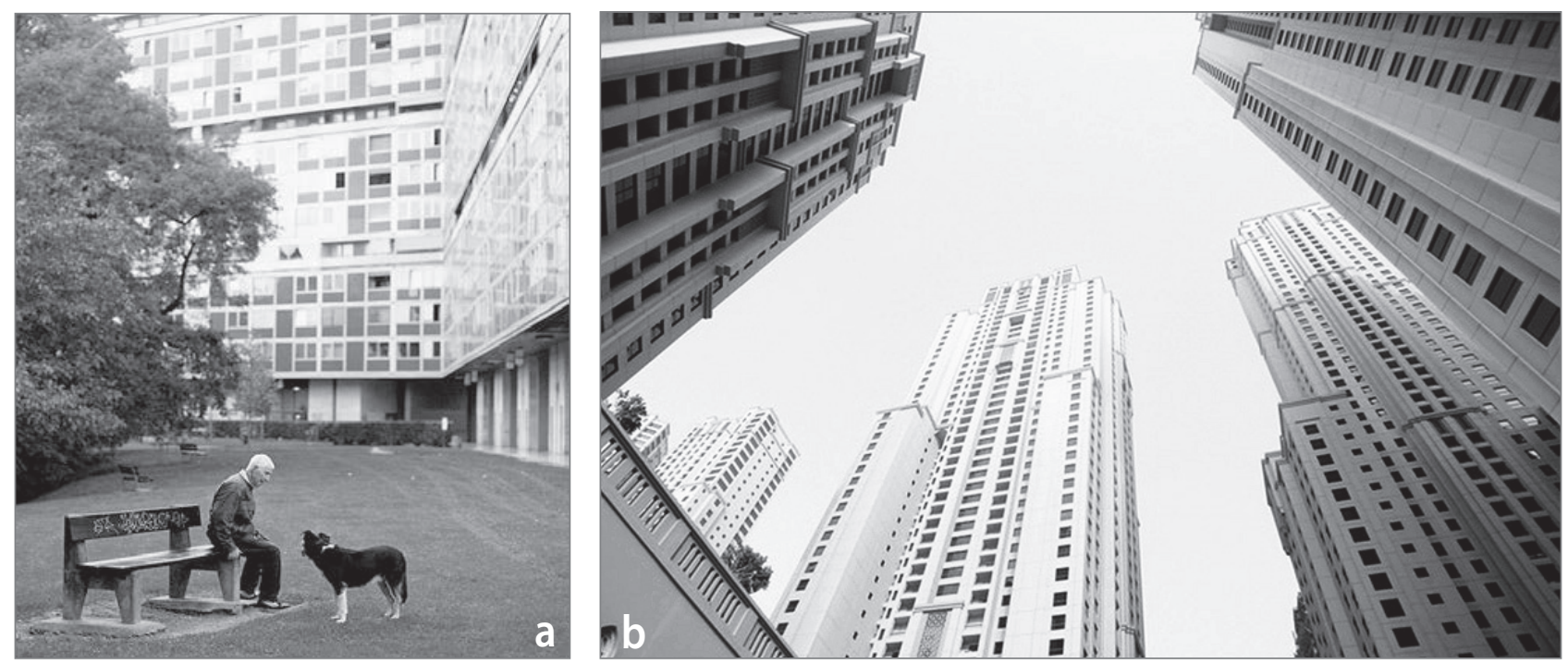

Slika 3: (a) stanovanjski kompleks v Le Lignonu v švicarski občini Vernier je bil zgrajen pred štiridesetimi leti v Le Corbusierjevem duhu ogromnih stanovanjskih kompleksov, ki naj bi služili kot stroj za bivanje; trenutno v njem živi 6.800 ljudi, v naslednjem desetletju pa nameravajo zgraditi še en tak kompleks; (b) stanovanjske stolpnice Jumeirah Beach Residence v Dubaju, kjer je nepremičninski trg izredno krhek (foto: (a) Christian Lutz; (b) Reuters). 
finančno porušil, kar je pripeljalo do globalnega gospodarskega opustošenja. Če bi mislili, da lahko še nekaj desetletij izkoriščamo to poceni netrajnostno rabo virov, bi nam bilo morda še odpuščeno. Vendar smo prav nasprotno dobro videli, da je tisto, kar je bilo ekološko, že postalo ekonomično, ali natančneje, kar je bilo »neekološko«, je postalo »neekonomično «.

To torej naznanja, kaj nas čaka. Naj bo jasno, za kaj gre: če se ne bomo odzvali na te izzive, verjetno celotno človeštvo čaka veliko bolj žalostna prihodnost. Izzivi se seveda ne nanašajo samo na grajeno okolje, vendar bo prav to zagotovo najpomembnejše. Kot potrjuje Le Corbusierjev primer, so poklici s področja okoljskega načrtovanja že vpleteni v krizo in od njih se bo vse bolj zahtevalo, naj krizo tudi učinkovito rešujejo.

Delo, ki ga opravljamo, ni več vzajemno podpirajoče, ampak lahko rečem, da je vsakršno kopičenje kontraproduktivno, in sicer do te mere, da vsak nov dodatek zmanjša vrednost celote /.../ Ni vedno jasno, ali svoj položaj izkoriščamo za sodelovanje v intelektualnem diskurzu ali za neverjetno egoistično razkazovanje. Na žalost svojemu poklicu nismo bili sposobni dati nobenega dostojanstva zaradi svoje popolne tehnične nesposobnosti obvladanja pritiskov na trgu in pripravlje- nosti na to, da se z nami popolnoma manipulira /.../ (Navedeno iz predavanja Rema Koolhaasa; objavljeno v La Giorgia, 2007: D1.2.)

Alkimistična obljuba modernizma - da bo količino pretvoril v kakovost $s$ pomočjo abstrakcije in ponavljanja - ni bila izpolnjena; šlo je za potegavščino oziroma čarovnijo, ki ni delovala. Vsi poskusi novega začetka so samo diskreditirali zamisel o novem začetku. Ta polom je pustil ogromen krater v našem razumevanju modernosti in modernizacije. (Koolhaas, 1995: 961.)

\section{Odgovornost Rema Koolhaasa}

Arhitekt Rem Koolhaas je morda najglasnejši zagovornik stališča, ki je v široki rabi v postmodernih oblikovalskih poklicih in njihovih akademskih okoljih. Jasno kritizira neuspehe utopičnega modernizma Le Corbusierja in drugih pionirjev in globoko omejeni svetovni nazor, ki ga je zapustil postmodernistom. Njegova razlaga je tako uporabna, da je prav, da na kratko predstavimo njene najpomembnejše teme. Koolhaas s prstom pokaže na osrednji problem: »Delo, ki ga opravljamo, ni več vzajemno podpirajoče /.../ / in celo kontraproduktivno, in sicer do te mere, $\gg$ da vsak nov dodatek zmanjša vrednost

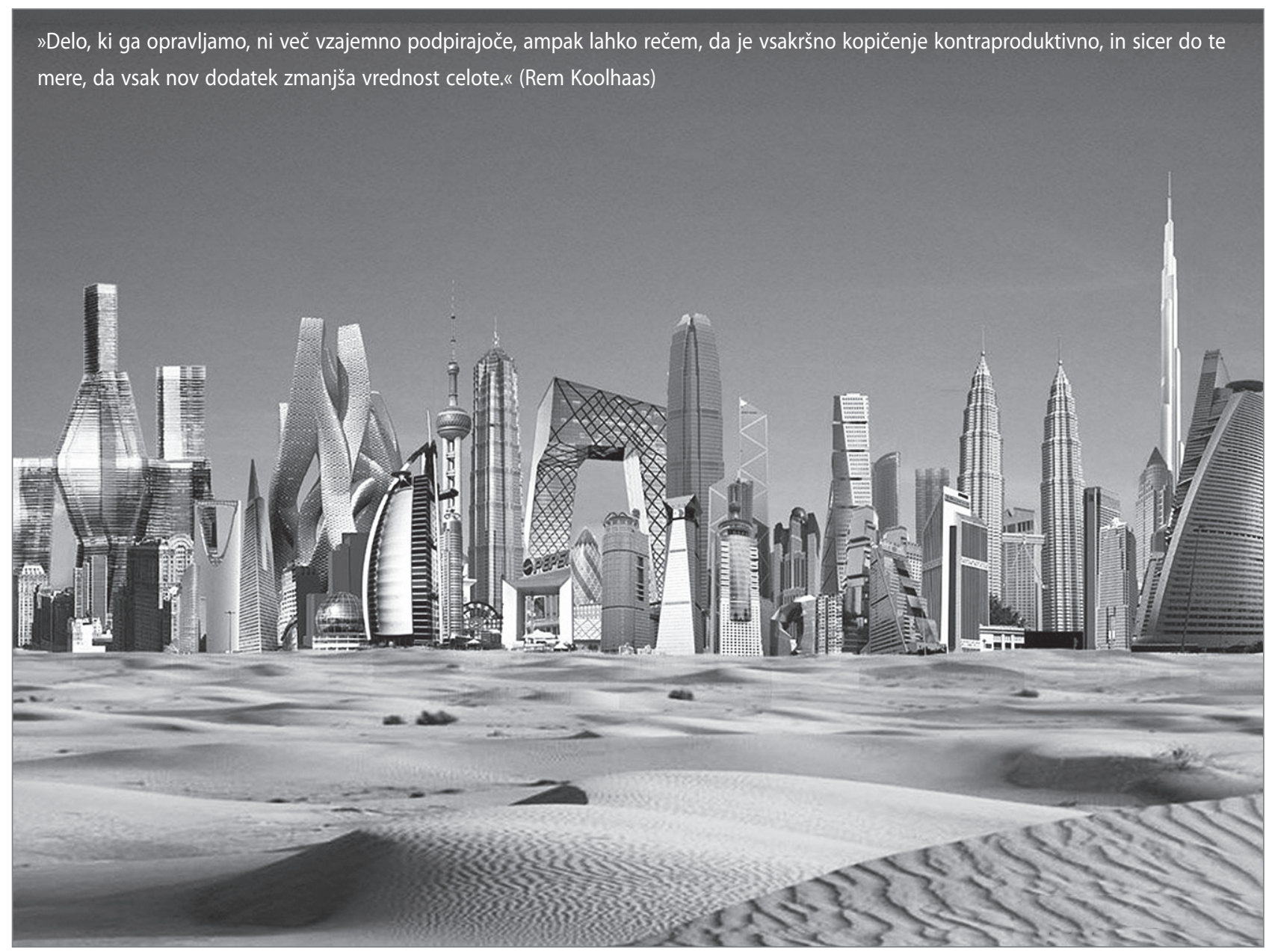

Slika 4: Nič več vzajemno podpirajoči? Koolhaas je prikazal simulirano puščavsko pokrajino, posejano z najpomembnejšimi projekti »zvezdniških« arhitektov (trg proti pomenu) (foto: urad za metropolitansko arhitekturo; vir: Helie, 2007). 
celote.« Čisti izkupiček prizadevanj vodilnih arhitektov je morda res le egoistično razkazovanje (Helie, 2007; glej sliko 4).

Tako eden najuspešnejših in najprodornejših arhitektov na svetu odkrito in morda celo nekoliko presenetljivo trdi, da njegov poklic zares zmanjǔuje »vrednost « (kot se je sam izrazil) grajenega sveta - zagotovo ne načrtno, ampak zaradi nezmožnosti ustvarjanja večjih celot vrednosti iz posameznih dejanj. Po njegovem mnenju do tega prihaja zato, ker z nami manipulirajo večje sile, in sicer najizraziteje pritiski na trgu. V članku Whatever happened to urbanism? (Kaj se je vendar zgodilo z urbanizmom?) prav tako krivi mehanski tehnološki pristop, ki je poskušal »količino pretvoriti $\mathrm{v}$ kakovost $\mathrm{s}$ pomočjo abstrakcije in ponavljanja « (Koolhaas, 1995: 959). Ta alkimistični poskus se je sprevrgel v polom oziroma »čarovnijo, ki ni delovala «. Vendar iz tega položaja, ki ne vodi v nič dobrega, ne ponuja obetavne poti naprej - verjetno zato, ker zares ne vidi izhoda. Pravi, da smo obtičali v nekakšnem »kraterju modernosti in modernizacije «. Čeprav smo (poklici s področja okoljskega načrtovanja) povzročili ta polom, ga ne moremo popraviti. Največ, kar lahko naredimo, je morda to, da izrazimo svoje razdrobljeno stanje in ga celo slavimo. »Kaj če razglasimo, da krize sploh ni? /.../ Dozdevni neuspeh urbanega ponuja izjemno priložnost, izgovor za ničejansko lahkomiselnost. Zamisliti si moramo 1.001 drugi koncept mesta, nerazumno tvegati, upati si biti popolnoma nekritični, globoko požreti in odpuščati levo in desno. Verjetnost neuspeha mora biti naš smejalni plin/kisik, modernizacija pa naše najmočnejše mamilo.« (Koolhaas, 1995: 959.) Svet se bliža koncu. Zabavajmo se!

»Tudi tega smo se naučili od vašega naroda - kartografiranja, « je dejal Mein Herr. »Vendar smo ga nato razvili še veliko bolje kot vi. Kakšen, menite, bi bil največji zemljevid, ki bi bil zares uporaben?«

$\gg V$ merilu okrog šest palcev proti eni milji.«

»Samo šest palcev! « je vzkliknil Mein Herr. »Mi smo kmalu prišli na šest jardov proti eni milji. Nato smo poskusili s sto jardi proti eni milji. Nato pa smo dobili najveličastnejšo zamisel! Dejansko smo izdelali zemljevid države v merilu ena milja proti eni milji!«

»Ga veliko uporabljate? « sem vprašal.

»Še nikoli ga nismo razgrnili, « je rekel Mein Herr. »Kmetje se s tem niso strinjali; rekli so, da bi pokril celo državo in zakril sonce! Zato zdaj za zemljevid uporabljamo kar državo in zagotavljam vama, da je skoraj enako učinkovito.«

Carroll in Furniss (1893: 169)

Koolhaasovo stališče je tesno povezano s tistim, ki ga je zagovarjala generacija poststrukturalističnih filozofov in teoretikov umetnosti (tri najpomembnejše celo navaja v eseju Whatever happened to urbanism?). Kot Mein Herr v očarljivi pripove- di Lewisa Carrolla so bili ti misleci priča prizadevanjem za oblikovanje vse natančnejših racionalnih predstavitev sveta; na koncu so ugotovili, da je ves projekt nekako absurdistično propadel (slika 5). Izčrpna (in pravična) obravnava njihovih idej presega obseg in namen tega članka. Znani so po tem, da so zagovarjali izrazite omejitve razuma kot orodja za zvesto zajemanje vsakršne domnevno »objektivne « realnosti ter $\mathrm{v}$ nasprotju $s$ tem poskušali poudariti sintetične in celo samovoljne konstrukcije jezika in umetnosti. Menili so, da to stanje pušča možnost, da tisti, ki imajo politično ali gospodarsko moč, močno zlorabijo jezik in umetnost; svojo moč uporabljajo za uveljavljanje »duhovniških « zahtev po »objektivnem « znanju, s čimer še povečujejo svojo moč. Zato je pomembna naloga umetnika ta, da »dekonstruira « tovrstna besedila in tako razkrije te pripovedi moči.

Poststrukturalizem v svojem bistvu zanika možnost skupne predstave vrednosti, če se do nje lahko dostopa kot do neodvisnega pojava s skupnimi idejami jezika. Tovrstne vrednosti se oblikujejo tudi individualno, prav tako kot se individualno oblikuje pomen v jeziku. Pustiti moramo, da se ta proces $s$ pristopom »od spodaj navzgor « razvije raznoliko in plura-
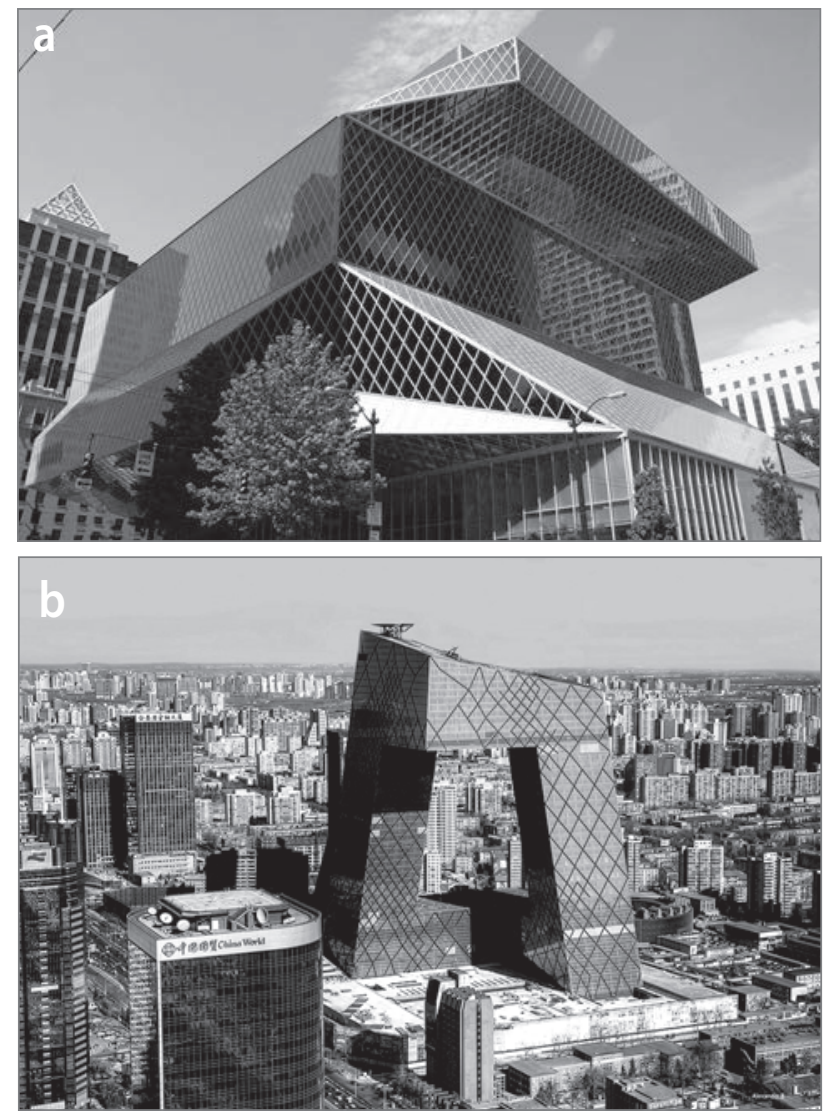

Slika 5: Poststrukturalistične ideje na delu $v$ različnih kontekstih in urbanih okoljih, v katerih splošna posturbana arhitektura izraža ideje globalnih tokov denarja, medijev, moči in transurbanističnih sinergij modernizacije, globalizacije in transformacije; (a) splošna knjižnica Rema Koolhaasa v Seattlu; (b) osrednja stavba kitajske televizije (foto: (a) Scott Larsen; (b) Alexander B. Tutti). 
listično, saj je edina druga možnost uvedba umetnih okvirov pristopov »od zgoraj navzdol «. To pa bi bila napaka fundacionalizma - neupravičena politična ali intelektualna hegemonija. Vendar je prav v tem pogledu ta prodorna akademska filozofija osnovni problem za vsakogar, ki želi » izboljšati kakovost « grajenega okolja ali prevzeti kakršen koli drug skupni projekt, ki predvideva določeno obliko normativnega standarda (ki zelo

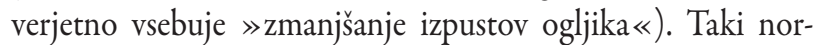
mativni standardi namreč predvidevajo neodvisno vrednost, določeno na podlagi neodvisne osnove. Vendar bi že samo predlaganje te možnosti pomenilo materializacijo vrednosti in obliko hegemonije nad človekovo zmožnostjo, da konstruira (in dekonstruira) zase, ne glede na svojo teorijo vrednosti.

To nakazuje zanimivo vrsto logičnih problemov, povezanih s tem »dekonstruktivističnim « filozofskim pristopom. Te probleme so podrobno obravnavali številni filozofi in znanstveniki, vendar tu niso predstavljeni, ker to presega namen tega članka. Vsebujejo pa resne logične težave s samo zmožnostjo opravljanja znanstvene dejavnosti, ki presega le pisanje zabavnih zgodb (razvpita ostra kritika fizika Allana Sokala, objavljena v knjigi Fashionable nonsense (Modni nesmisel) - glej Sokal in Bricmont, 1998 -, je samo en primer tovrstne kritike). Vprašanje je tudi, kako lahko kritiziramo fundacionalizem, če obenem očitno stojimo na svojem skonstruiranem fundacionalizmu - to je poststrukturalističnem svetovnem nazoru. »Poznam resnico in ta je, da ni resnice! « Vendar pa to odpira vprašanje: »Kako pa to veš? « (Glej Habermas, 1987; Davis, 2004.) Še več, medtem ko je ta umetni, neokantovski (in nenavadno pozitivistični) pogled na ontologijo zgodovinsko in filozofsko zanimiv, nazadnje kot način mišljenja, ki bi usmerjal človekova dejanja, ni uporaben. Pravzaprav se zdi, da pooseblja veliko zmedo glede ontološke uporabnosti jezika, za katero se napačno predvideva, da se popolnoma sklada z realnostjo. Ko se ugotovi vse več neskladnosti, se umaknemo na stalǐ̌če, da je jezik poljubno umeten in da kot to pravi Jacques Derrida (1967: 158), »zunaj besedila ni ničesar «. Seveda to nima nič skupnega z bistvom, da je jezik vedno nepopoln (in seveda umeten) približek, vendar je kljub temu uporaben. To je čudovita poanta očarljive pripovedi Lewisa Carrolla in Harryja Furnissa (1893).

To stališče je tudi zabavno protislovno - $s$ katerega stališča lahko trdiš, da je jezik »poljubno « umeten, če ne s stališča zunaj jezika? Kje pa je to, če trdiš, »da zunaj besedila ni ničesar «? Če obstaja samo »znotraj jezika «, moram na vaše izjave gledati kot na vašo sintezo in ne svojo. Zakaj bi pripisoval poseben pomen vašim izjavam glede jezika - zakaj jih ne bi preprosto dekonstruiral v skladu s svojimi konstruiranimi pomeni? Zakaj vas ne bi potrepljal po ramenu v zahvalo za vaše nepomembno cviljenje in godrnjanje? Nazadnje tu preprosto ni nikakršne praktično uporabne epistemologije. Naj-

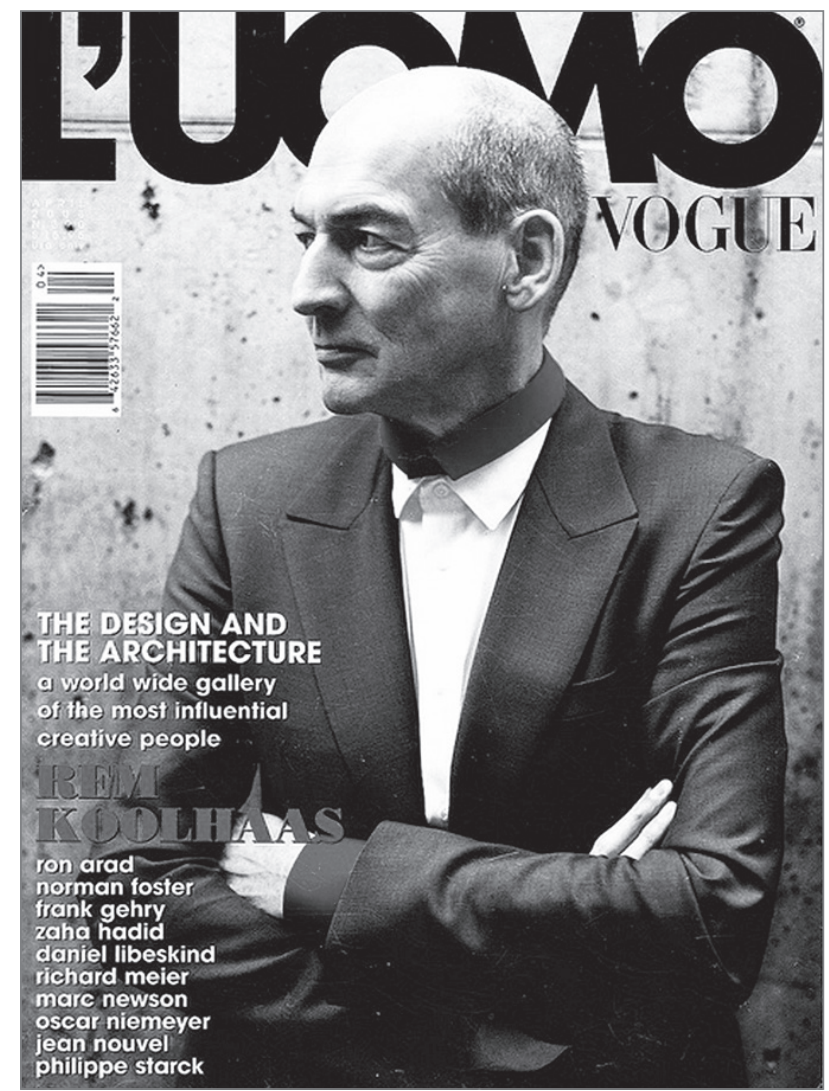

Slika 6: Hagiografska reportaža o Remu Koolhaasu v reviji L'Uomo Vogue, objavljena aprila 2008 (foto: Mark Seliger).

večja škoda pa je to, da ta samougasljiva logika velja tudi za grajeno okolje. Če nobeno arhitekturno dejanje ni nič več kot umetniška konstrukcija osebnih pomenov, se nam torej ni treba ubadati $s$ tem, kaj počnejo drugi, ker je to njihova in ne naša konstrukcija, in ne smemo domnevati, da obstaja kaka skupna domena, ter gotovo njihovemu delu ne smemo vsiliti svojih teorij vrednosti. Lahko objokujemo izgubo koherence ali pa hegemonijo denarja in tržnih sil, vendar ne smemo poskušati » rekonstruirati « v skladu z normativnimi standardi kakovosti. Vsakršen tak standard lahko dekonstruiramo, celo domnevno »najobjektivnejše «, kot je zmanjšanje izpustov $\mathrm{CO}_{2}$ - nazadnje imajo celo rastline raje $\mathrm{CO}_{2}$.

Zdaj lahko vidimo, kaj je v resnici Koolhaasov »krater modernosti « - najboljše umetniško dovoljenje. Težava ni v našem početju, ampak v sami naravi jezika in idej. Kot to pove Koolhaas na svoj značilno odkriti in osupljivi način: »Ker nismo odgovorni, moramo postati neodgovorni.« (1995: 971.) Logična posledica te maksime je samoizpolnjujoča se prerokba: ker verjamemo, da nimamo izbire, je tudi dejansko nimamo. Če verjamemo, da skupna teorija normativne vrednosti v grajenem okolju, ki bi služila kot osnova, ki bi nas usmerjala pri »čiččenju svoje nesnage «, ni mogoča, potem resnično ni mogoča - ker bomo preprosto nehali razvijati vsakršno možnost, da bi bila. Ne moremo razviti skupnega okvira učinkovitih ukrepov, ker verjamemo, da bi to prekršilo pravice drugih, da oblikujejo 
svoje individualne konstrukcije. Z vidika grajenega okolja je to velik neuspeh poststrukturalističnega razmišljanja: vsakršno priložnost skupnega ukrepanja že na začetku prostovoljno zapravimo, saj zavračamo skupne okvire takega ukrepanja. Če parafraziramo Koolhaasa: »Ker verjamemo, da nismo odgovorni, ne smemo preprosto uživati, medtem ko smo neodgovorni.« Morali bi tudi kritizirati tiste, ki si upajo poskušati biti »odgovorni « - kot tisti, tako Koolhaas, ki konstruirajo $\gg$ novi urbanizem «, ki temelji na dvojni iluziji reda in vsemogočnosti. Tako ti »izboljševalci sveta « grešijo, saj vztrajajo pri fundacionalizmu. Nasprotno, če naj bi tak »novi urbanizem « obstajal, »se ne bi smel več osredotočati na brezhibne definicije in vsiljevanje mej, ampak na vključevanje novih pojmov in zavračanje mej /.../ (Koolhaas, 1995: 959.) Skratka, vse je mogoče - razen, kot se zdi, to, da se problemi dejansko poskušajo reševati (slika 6).

\section{4 "Organizirana kompleksnost» Jane Jacobs}

Urbanistka Jane Jacobs je bila med prvimi, ki so opisali zgodovinski pojav sodobnih kompleksnih sistemov, pri čemer je trdila, da okoljski načrtovalci zares lahko učinkovito rešujejo pereča vprašanja, ki so pred nami (Jacobs, 1961). V knjigi The death and life of great American cities (Umiranje in življenje velikih ameriških mest) je zapisala (1961: 428):

Da bi o mestih razmišljali in dejansko prišli do nekih sklepov, je treba predvsem vedeti, kakšen problem sploh predstavljajo mesta, saj ne moremo o vseh problemih razmišljati na enak način. Kateri načini razmišljanja bodo uporabni in nam bodo pomagali razkriti resnico, ni odvisno od tega, kako običajno najraje razmišljamo o določenem predmetu, ampak od inherentne narave predmeta.

Med vsemi revolucionarnimi spremembami v zadnjem stoletju so morda najpomembnejše spremembe miselnih metod, s katerimi lahko raziskujemo svet /.../ Mesta predstavljajo probleme organizirane kompleksnosti, tako kot biosistemske vede. Predstavljajo »okoliščine, $\mathrm{v}$ katerih se pol ducata ali celo več ducatov količin razlikuje sočasno in na komaj opazne, med seboj povezane načine «. Mesta, tako kot biosistemske vede, ne predstavljajo enega problema v organizirani kompleksnosti, ki lahko razloži vse drugo, če ga razumemo. Pri analizi jih lahko razdelimo v številne probleme ali segmente, ki so med seboj tudi povezani, tako kot v primeru biosistemskih ved. Spremenljivk je več, vendar niso brez repa in glave; » povezane so v organsko celoto «.

Pri določenih predelih mest, ki v nekaterih pogledih delujejo dobro, v nekaterih pa slabo (kar je pogosto), sploh ne moremo analizirati njihovih dobrih in slabih lastnosti, določiti težav ali pa razmisliti o koristnih spremembah, če jih ne obravnavamo kot probleme organizirane kompleksnosti.
J. Jacobs poudarja, da so se statistične in mehanske vede devetnajstega stoletja počasi umikale novim vedam, ki jih je opisala kot »organizirano kompleksnost «; gre za sisteme, za katere je značilna vrsta medsebojno interaktivnih spremenljivk, ki so »povezane v organsko celoto «. To je bil pomemben vpogled, ki so ga ponujale biološke vede in naj bi pomagal razložiti nepretrgano delovanje ekosistemov, genskih procesov in še marsikaj drugega. Pomemben uvid Jane Jacobs pa je bil ta, da vse to lahko pomaga razumeti tudi delovanje mest in kako lahko posredujemo, »določimo težave ali razmislimo o koristnih spremembah «, da odpravimo njihove težave, in kot to nakazuje v svojem naslovu, urbano »umiranje « (propadanje in slabo delovanje) pretvorimo $\mathrm{v} \gg$ življenje $\ll$ (dinamičnost in uspeh; slika 7). Problem je bil po njenem mnenju v tem, da so okoljski načrtovalci obtičali v pristopu »od zgoraj navzdol « oziroma v zastarelem mehanskem ali statističnem pogledu na vesolje, ki čeprav je bil tehnološko produktiven, preprosto ni zadostno razložil, »kakšen problem v resnici predstavlja mesto «; zato je mestom naredil veliko škode in pustil veliko njihovih najhujših problemov nerešenih. J. Jacobs je to kritizirala vse življenje, $v$ kritiko pa je nato zajela tudi ekonomijo, akademsko teorijo, organizacijsko teorijo in nevarnosti prevelike specializacije, in sicer še najizraziteje v svoji zadnji, ikonoklastični knjigi Dark age abead (Pred nami so temni časi; Jacobs, 1994).

Drugi teoretiki iz tega obdobja so ugotavljali podobno. Arhitekt Christopher Alexander, nekdanji matematik, je v svojem

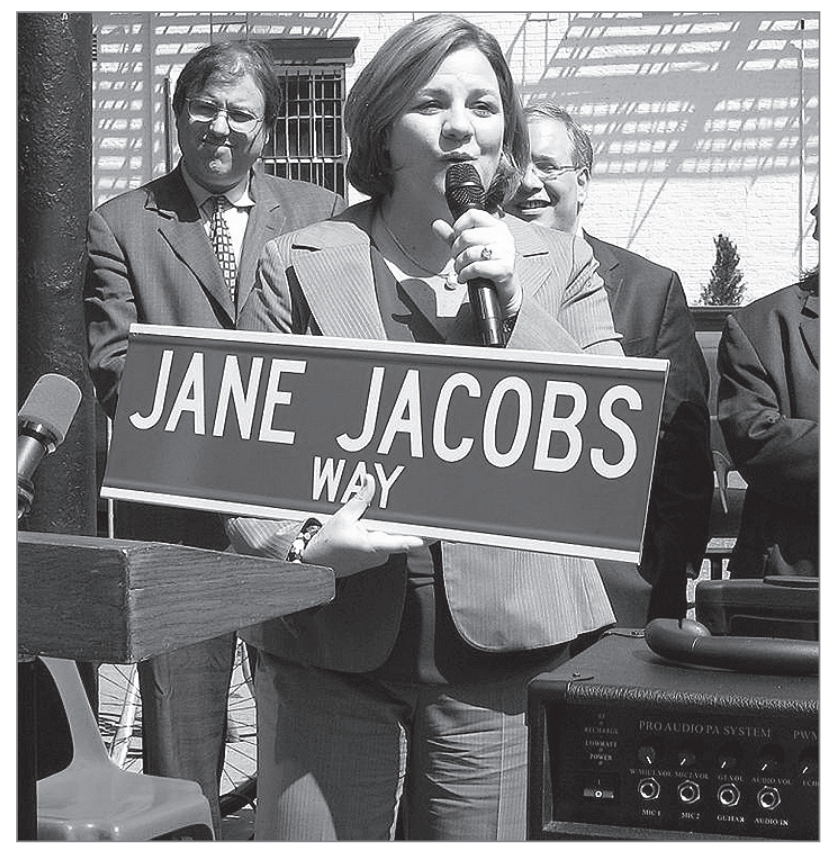

Slika 7: Predsednica newyorškega mestnega sveta Christine Quinn med govorom $v$ čast Jane Jacobs: del ulice Hudson Street - med ulicama Perry Street in West 11th Street -, v katerem je živela pisateljica in urbana aktivistka Jane Jacobs, so leta 2009 preimenovali v Jane Jacobs Way (Pot Jane Jacobs). Kljub temu se številni arhitekti in načrtovalci zavzemajo za to, da bi se J. Jacobs »na novo ocenilo« in marginaliziralo njene silovite kritike (foto: Stephanie Lam). 
prelomnem članku z naslovom $A$ city is not a tree (Mesto ni drevo; 1964) opisal zmoto oblikovanja struktur mest kot skupin togih, drevesom podobnih hierarhij, in nezmožnost razumevanja medsebojne povezanosti (»organizirane kompleksnosti« Jane Jacobs), ki je posledica naravne rasti mest. Zaradi tega so bili novi mestni načrti tudi sami togi, drevesom podobni; prerezali so povezujočo se kompleksnost naravnih mest. To je bilo izredno uničujoče za mesta, in sicer enako, kot je za biološko tkivo uničujoče, če ga prerežemo. Alexander je trdil, da ta problem izvira iz človeškega pojmovanja sveta. Poenostavljamo, abstrahiramo in izpuščamo bistvene povezave. Če delamo to preudarno in pri tem puščamo prostor za iterativne prilagoditve in popravke, lahko sistemom, $s$ katerimi delamo, omogočimo, da obnovijo svojo osnovno medsebojno povezanost $s$ pomočjo razvijajočega se procesa. Če tega ne bomo storili, bomo te sisteme najverjetneje uničili, pa naj gre za žive organizme, ekosisteme ali mesta.

Obstajata teoriji, ki zelo dobro pojasnita Koolhaasov »krater modernosti «. Dobro se ujemata z njegovo analizo neuspešnosti (zgodnjih) modernih idej racionalne preprostosti. Vendar pa gresta še korak dlje, saj ugotavljata, da smo blizu novemu razumevanju kompleksnih in živih sistemov - in čas je, da izkoristimo svoje nove vpoglede. Kot pravi J. Jacobs (1961: 433), »novejši napredek biosistemskih ved sporoča nekaj izredno pomembnega o drugih problemih organizirane kompleksnosti. Sporoča, da se tovrstni problemi labko analizirajo - da jih je edino smiselno upoštevati kot take, ki se jih da razumeti, in ne, kot to pravi dr. Weaver, kot da so ,na neki temačen in moreč način neracionalne $\ll$. Ti in drugi znanstveni napredki nam dajejo nov, izredno uporaben okvir za opazovanje sveta narave in sveta človeške narave. Ne gre za » dokončno objektivno realnost « - saj kaj takega sploh ne obstaja. Poststrukturalisti imajo prav, ko pravijo, da je znanje vedno skonstruirano. Vendar pa je skrajno neumno zanikati delovni predlog, naj se znanje konstruira v simetričnem razmerju do »nečesa realnega « oziroma nečesa skupnega.

Da smo lahko inteligentni v kakršnem koli pomenu besede in obenem ne trpimo za usodno » paralizo analize«, potrebujemo začasen poenoten pogled na svoje probleme oziroma delovno poenoteno teorijo samih sebe in tistega, kar počnemo. Ta pristop lahko združuje in izkorišča vse druge vpoglede, ki so nam na voljo - biolog Edward Osborne Wilson je to poimenoval »skladnost « (ang. consilience). Vsebuje lahko tudi poststrukturalistično zaskrbljenost o dokončnosti znanja, ne pa tudi njihovega absurdističnega carrollianskega odgovora. J. Jacobs je v analizi opozorila na ostanke zapuščine » napačnih rab « - idej, ki niso več koristne, če so sploh kdaj bile, vendar se še vedno pogosto uporabljajo, imajo velik vpliv in zavirajo napredek (slika 8). Kot pravi, »so nam te napačne rabe v napoto; moramo jih spraviti na plano, jih prepoznati kot neuporabne strategije mišljenja in zavreči« (Jacobs, 1961: 435).

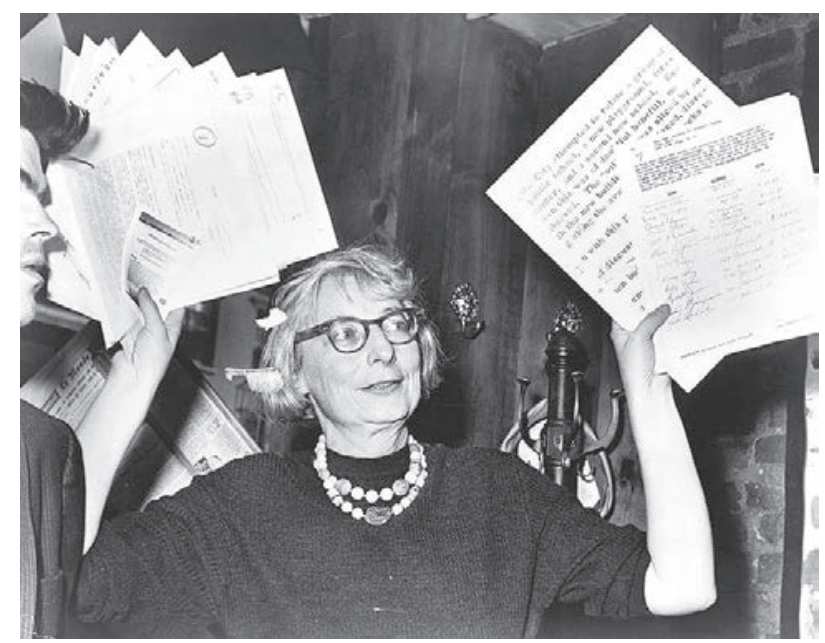

Slika 8: Jacobsova kaže dokumentarno gradivo na sestanku odbora za reševanje West Villagea - skupine, ki je nasprotovala katastrofalnim načrtom Roberta Mosesa za izgradnjo avtoceste skozi Manhattan; Jacobsova in njena skupina sta bitko tudi dobili (foto: kongresna knjižnica).

\section{Najpomembnejše »napačne rabe»}

Zato tukaj predstavljamo kratek seznam desetih največjih tovrstnih » napačnih rab « in prilagamo opis, s čim bi jih morali nemudoma zamenjati, če želimo doseči resničen napredek pri reševanju perečih vprašanj:

- Napačna raba kvantitativnega tehničnega razmišljanja Statistično združevanje številk ima svoj pomen, vendar se pri tem pogosto izpustijo najpomembnejši deli zgodbe. Poleg tega so lahko kompleksni sistemi nedoumljivi »razen če « za njihovo razumevanje uporabljamo nove kvalitativne lastnosti.

- Napačna raba linearnega in mehanskega razmišljanja To razmišljanje ima prav tako svoj pomen, vendar ga moramo zdaj dopolniti z razumevanjem vzajemno prilagodljivih sistemov in razpoložljivih učinkovitih interdisciplinarnih modelov, ki so potrebni za njihovo upravljanje.

- Napačna raba specializacije

Kritični učinki človeške dejavnosti kot celote, ki se pojavljajo, izvirajo iz interakcij številnih dejavnikov po načelu sistemov, ki temeljijo na pravilih. To »obsežno igro $\mathrm{z}$ več igralci« moramo razumeti, kot tudi pravila, po katerih je oblikovana in je lahko tudi preoblikovana za omogočanje alternativnih izidov - skupaj z ekonomskimi, s pravnimi in tehničnimi pravili. Interdisciplinarne teme, kot je teorija iger, moramo sprejeti z novim zagonom. Sprejeti moramo nove modele sodelovanja in $\gg$ prosto dostopnega « razvoja, katerih logična posledica so povezujoče transformacije kompleksnih procesov. Specializacija, predvsem akademska, pomeni smrt zmožnosti upravljanja teh kritičnih strukturnih povezav. Vendar učinkovito interdisciplinarno razmišljanje prav tako zahteva veliko natančnosti. 
- Napačna raba »teorije stvari« (ang. thing theory) kot način razlaganja grajenega okolja

»Teorija stvari « nas je pustila na cedilu, še zlasti v izredno patološkem in slabo prilagojenem svetu ikonične arhitekture. Namesto nje potrebujemo teorijo povezanih in moduliranih mrež premikanja, vida in zvoka - ki razume in upravlja večplastne prostorske sisteme javnih, poljavnih, polzasebnih in zasebnih prostorov. Urbanistično oblikovanje se mora vrniti $k$ umetelnemu oblikovanju teh prostorov kot izhodiščni pogoj ter kot del plodne strategije njihovega nepretrganega razvoja in obnavljanja.

- Napačna raba arbitekturnega urbanizma kot zbirke umetniško-arbitekturnih predmetov

Neverjetno je, da se kompleksni urbanizem še vedno nadomešča $\mathrm{z}$ ozkoglednim pristopom do urbanizma, $\mathrm{v}$ skladu $s$ katerim se projekti gradijo $\mathrm{v}$ smislu $\gg$ galerije skulptur «; to delajo arhitekti, ki se nimajo pravice vtikati v urbanistično oblikovanje. Umetnost (in umetnost arhitekture) mora zavzeti svoje odgovorno mesto med vedami, ki se ukvarjajo z naselji in ekologijo. $V$ šolah bi morali te predmete učiti v vsej njihovi kompleksnosti in jim nujno dati večji pomen.

- Napačna raba umetnosti arbitekture, ki naj bi bila sestavljena predusem iz formalnih neoplazem

Namesto njih potrebujemo spretno oblikovane mutacije, prilagojene resničnim biološkim in biofilnim potrebam. Potrebujemo obliko, ki temelji na dokazih in ni ustvarjena v linearnem ali mehanskem smislu, temveč $\mathrm{v}$ vzajemno prilagodljivem in evolucijskem smislu, ki temelji na vzorcih. $V$ središče oblikovalskega procesa moramo postaviti človeka, ne pa modnega in izumirajočega neomodernizma, ki ni ne prilagodljiv ne primeren. Če ne bomo opustili te poljubno omejene in neuspešne oblike jezika, je arhitektura obsojena na večno zlorabo.

- Napačna raba antidiahronične teorije zgodovine

Na prvi pogled je bil modernizem pomanjkljiva teorija zgodovine oziroma nekakšna utopična lažniva obljuba, da smo »dosegli« končno idealno stanje in konec zgodovine. Postmodernizem, ki kritizira to stanje, pa pravzaprav ohranja to prevaro, le da utopizem zamenja za obupavajoč nihilizem. Namesto tega moramo razumeti trajno diahronično naravo kulture in evolucijski svet, $\mathrm{v}$ katerem obstaja: nenehne evolucijske procese, ki proizvajajo vedno nove novosti, vendar tudi pomembno vključujejo zgodovino, spomin, vzorce in ponovno pojavljanje. Moramo se učiti iz zgodovine, ponavljati njene uspehe in prečistiti (vendar ne popolnoma zavreči) njene neuspehe. Med radikalnim zavračanjem smo namreč zavrgli tudi našo zmožnost učenja. Ta skupna izguba spomina bo usodna.

- Napačna raba teorij fragmentacije

To je spet samo del zgodbe. Potrebujemo namreč teorije konvergence in teorije popolnosti, ki jo lahko dosežemo tako, da pogledamo, kako se ta dejansko dosega v naravnih sistemih. Na tem pomembnem področju velja opozoriti na delo Christopherja Alexandra, ki je vplivalo tudi na fizike, kot je bil David Bohm, in biologe, kot je bil Brian Goodwin.

- Napačna raba modnega, vendar nazadnje nesmiselnega anarhizma

Pogosto se dogaja, da je obseg dejavnosti prevelik, zato je primerno, da se ta problem obravnava in da se škodljivi večji objekti porušijo. Res pa je tudi, da je prej ali slej čas za obnovo in nimamo druge izbire, kot da najdemo najboljši pristop do nje. Če tega ne naredimo, sebe izpostavimo drugim, ki bodo rade volje to naredili namesto nas, čeprav slabo in le zaradi svojih ozkih interesov; lahko rečemo, da gre za nekakšen gangsterizem. To hibo pogosto najdemo $\mathrm{v}$ ekonomskem konservatizmu, poleg tega pa je to, kot je ugotovil Jürgen Habermas (1987), tudi razlog, da je poststrukturalizem, $v$ pravem pomenu besede, oblika konservatizma - če domnevamo, da »ne moremo ničesar storiti«.

- Napačna raba poststrukturalizma

Kot smo tukaj samo namignili, se iz različnih ved in med pozornimi filozofi razvija nekakšen neostrukturalizem. Medtem ko sočustvujejo z nasprotovanjem fundacionalizmu, se zdi, da je lahko »zdravilo « poststrukturalizma veliko smrtonosnejše kot sama bolezen in vodi v pohabljenje človeške inteligence, ko si to lahko najmanj privoščimo.

J. Jacobs je trdila, da vendarle imamo moč, da tovrstne napačne rabe popravimo, če se za to odločimo, prav tako, kot smo se jih odločili ustvariti. Le bolj se moramo začeti zanimati, za kakšen problem dejansko gre - v našem primeru za »problem, ki ga predstavlja mesto « (Jacobs, 1961: 429).

\section{Sklep}

Strokovnjaki s področja okoljskega načrtovanja se nedvomno soočajo $\mathrm{z}$ nezavidljivimi in $s$ strah zbujajočimi izzivi: razdrobljena gradnja, tratenje in izčrpavanje virov, ogrožanje zdravja in dobrega počutja, ekološka škoda, za povrhu pa še sedanja gospodarska kriza, povezana z napakami v grajenem okolju. Kar je še slabše, veliko teh okoliščin je mogoče neposredno povezati z napakami, ki so jih v preteklosti storili strokovnjaki s področja okoljskega načrtovanja.

Kako pa so se na to doslej odzivali? Kot smo videli, se vodilni strokovnjaki s tega področja na krizo, ki jo je povzročila njihova stroka, niso odzvali tako, da bi se soočili s svojo globljo poklicno odgovornostjo in poskušali popraviti človeška okolja, ki jih je njihova stroka pokvarila. Raje so se odločili umakniti v teo- 
rije samoopravičevanja, zeleno zavajanje (ang. greenwashing) in še bolj nenavadne estetske norosti, ki jih $\mathrm{v}$ dobičkonosni embalaži prodajajo zbeganim in slabo obveščenim strankam. Zadnje čase novo gibanje v urbanističnem načrtovanju in oblikovanju - »krajinski urbanizem « - osuplja z visokotehnološkim zelenjem: vključuje na primer visokotehnološko infrastrukturo za usmerjanje vodnega toka in zahteva gromozanske, drage in zapletene posege na lokacijah. Obenem pa izrazito rade volje sprejema redko poseljena in od avtomobilov odvisna predmestja - platna za dela okoljsko avantgardne visoke umetnosti. Spremlja pa ga tudi nova aglomeracija težko razumljive teorije, razvite za to, da zbega in navdušuje neizbrane (Mehaffy, 2010; Kunstler, 2011).

Če bi šlo za medicinske strokovnjake, bi bili najverjetneje deležni kazenske ovadbe zaradi poklicne malomarnosti. Govorimo pa o strokovnjakih s področja okoljskega načrtovanja, ki rade volje nadaljujejo svoje dobičkonosno početje, pri čemer ponavljajo stare napake in se ne ozirajo na posledice. Postajajo nevarno izolirani, pri čemer se še vedno ne zavedajo odgovornosti in priložnosti, ki jih ponuja sodobna znanost, ali preporoda, ki se lahko pojavi. Upajmo in vztrajajmo, da se bo ta odnos kmalu spremenil.

\section{Michael W. Mehaffy}

Sustasis Foundation, Lake Oswego, Oregon, Združene države Amerike

E-pošta: michael.mehaffy@gmail.com

\section{Tigran Haas}

Massachusetts Institute of Technology, Media Lab, Cambridge, Massachusetts, Združene države Amerike

E-pošta: tigran@mit.edu

\section{Opombe}

[1] Avtorja sta sodelovala pri raziskavi, ki potrjuje, kako silovito je povečanje teh izpustov; izsledki raziskave so bili predstavljeni na informativnem sestanku za COP-15 v okviru konference o podnebnih spremembah, ki je leta 2009 potekala v Köbenhavnu. Članek in povezave lahko najdete na http://www.planetizen.com/node/41801.

\section{Viri in literatura}

Alexander, C. (1965): A city is not a tree. Architectural Forum, 122(1), april 1965, str. 58-62.

Burchell, R. W., Lowenstein, G., Dolphin, W. R., Galley, C. C., Downs, A., Seskin, S., idr. (2002): Costs of sprawl - 2000. Raziskovalno poročilo. Washington, Transportation Research Board.

Carroll, L., in Furniss, H. (1893): Sylvie and Bruno concluded. London, Macmillan.

Davis, C. (2004): After poststructuralism: Reading, stories and theory. London, Routledge.

De Decker, P., in Newton, C. (2009): Ob padcu utopije [At the fall of
Utopia]. Urbani izziv, 20(2), str. 5-13 [74-82]. DOI: 10.5379/urbani-izziv-2009-20-02-001

Derrida, Jacques (1967): De la grammatologie. Pariz, Editions de Minuit.

Ebenezer, H. (1902): Garden cities of to-morrow. London, Schwan Sonnenschein \& Co., Ltd.

Frampton, K. (2005): Introduction: The work of architecture in the age of commodification. V: Saunders, W. S. (ur.): Commodification and spectacle in architecture: $A$ Harvard design reader, str. ix-xviii. Minneapolis, $\mathrm{MN}$, University of Minnesota Press.

Frumkin, H., Frank, L., in Jackson, R. (2004): Urban sprawl and public health: Designing, planning, building for healthy communities. Washington, DC, Island Press.

Habermas, J. (1987): The philosophical discourse of modernity: Twelve lectures. Cambridge, Polity Press \& Blackwell Publishers Ltd.

Helie, M. (2007): They can't work as a team. Dostopno na: http://emergenturbanism.com (sneto 10. 12. 2011).

Jacobs, J. (1961): The death and life of great American cities. New York, Random House \& Vintage Books.

Jacobs, J. (1994): Dark age ahead. New York, Random House.

Kellert, S. R., Heerwagen, J. H., in Mador, M. L. (2008): Biophilic design: The theory, science and practice of bringing buildings to life. Hoboken, NJ, John Wiley \& Sons.

Kellert, S. R., in Wilson, E. O. (1993): The biophilia hypothesis. Washington, DC, Island Press.

Koolhaas, R. (1995): Whatever happened to urbanism? V: Koolhaas, R., in Mau, B. (ur.): S, M, L, XL, str. 959-971. New York, Monicelli Press.

Kunstler, J. H. (2001): Godmother of the American city. Metropolis Magazine. Dostopno na: http://www.metropolismag.com (sneto 20. 12. 2011).

Kunstler, J. H. (2011): Back to the future: A road map for tomorrow's cities. Orion, julij/avgust 2011. Dostopno na: http://www.orionmagazine.org (sneto 20. 12. 2011).

La Giorgia, G. (2007): Market v. meaning. Architecture Week, 344(1), avgust 2007, str. D1.1-D1.

Le Corbusier (1923) (objavljeno leta 2008): Towards a new architecture. Miami, BN Publishing.

Le Corbusier (1935): La ville radieuse. Pariz, Editions de I'Architecture d'aujourd'hui, Fréal.

Le Corbusier (1967): Radiant city. London, Faber \& Faber.

Leinberger, C. B. (2008): Sprawl is the root cause of the financial crisis. Island press, Eco-Compass blog. Dostopno na: http://blog.islandpress.org (sneto 29. 10. 2011).

Lewis, C. (2011): Eisenman addresses admitted students, talks time and space. Yale Daily News, 12. 4. 2011. Dostopno na: http://www.yaledailynews.com (sneto 20. 12. 2011).

Mehaffy, M. (2010): The landscape urbanism: Sprawl in a pretty green dress? Planetizen. Dostopno na: http://www.planetizen.com (sneto 20. 12. 2011).

Program Združenih narodov za naselja (2011): Urban trends: Urban sprawl now a global problem. Nairobi, Earthscan.

Sokal, A., in Bricmont, J. (1998): Fashionable nonsense: Postmodern intellectuals' abuse of science. New York, Picador.

Wackernagel, M., Onisto, L., Linares, A. C., Lopez, F., Ina, S., Garcia, J. M., idr. (1997): Ecological footprint of nations. Prispevek je bil predstavljen na konferenci z naslovom Rio+5 Forum of the International Institute for Sustainable Development, ki je potekala od 13. do 19. marca v Riu de Janeiru v Braziliji. Tipkopis. 